\title{
Eros and Thanatos of Mr. Gessler Showing His Social Stratification in Galsworthys "Quality"
}

\author{
$1^{\text {st }}$ Pramudana Ihsan \\ English Education Department, Faculty of \\ Teacher Training and Education, \\ Universitas Muhammadiyah Surabaya \\ East Java, Indonesia. \\ pramudanaihsan@fkip.um-surabaya.ac.id
}

\begin{abstract}
The main goal of human in their life was achieving happiness because it would lead them into their motivation for creating a better life for themselves, but some people did not realize while they were gaining their pleasure or Eros. This paper was aimed at finding the Eros and Thanatos and also analyzing the stratification in Gesslers characteristics shown in "Quality" short story. The ways of finding the data of this paper were obtained using the qualitative method. Eros and Thanatos of Gessler happened since he needed to prolong his life by still keeping the traditional way of making shoes. This paper found out the Eros and Thanatos occured in Mr Gessler showed the social stratification of shoe maker. Indeed, he was poor since he needed long time to finish a perfect a pair of shoes but his Eros or pleasure showed up vividly and the thanatos kept him destruct a perfect shoe leather to be only for one pair of shoes even when machines could make better number. The Eros defined his social class not by his wealth but by his products he presumed.
\end{abstract}

Keywords-Eros, $\quad$ Thanatos, $\quad M r . \quad$ Gessler,
Galsworthys

\section{INTRODUCTION}

As human being, we want to life in the happiest atmosphere. It can be their satisfaction for fulfilling their pleasure then they will accept the risks toward their life whether the risks will be good or bad but they still stand for it. For the example, when you apply into favorite university as your happiness or Eros (life instinct) but the requirement you should pay a lot of money to enter that university as unpredictable thing or thanatos (death instinct) but you still accept it in order to enter in university but strata of people also affects this situation. It is in line with the theory that said by Wilson, "Happiness can be reached by many forms, either good or bad way. This joyful or happy feeling has a strong bound with the energy of life, as someone feels happy, he/she can get second energy and get another spirit" (Wilson, 2008, p. 255). Indeed, every single people will be through that situation as their immolation to achieve it.

Eros or thanatos and also stratification is included in "Quality" that is one of John Galsworthy literary works in 1912 because it consists of Mr.Gessler's live that talk about society issues and Mr. Gessler's pleasure for making boots without any aids but he feels that his boots will be a good boot which has quality when he conducts it by himself then it persuades the royal family just for buying a boot but the main thing that make this short story was interested to wit Eros and thanatos and his stratification that were reflected in "Quality". It is the things that make the researcher fascinated for analyzing Galsworthy's Quality as the subject in this study.

"Quality" is written by a great novelist and also playwright. Quality's author was born in 1867 as an English man and a good writer on literature. One of his famous literary works is Quality that he entered in this story as the narrator. His name is John Galsworthy. He has a lot of great literary works as well as Indian Summer of a Forsyte (1918), In Chancery (1920), Awakening (1920), and To Let (1921) that successfully trigger his readers's interested for always reading his book, he also receives an award in 1932 as Nobel Prize in literature. In his literary works mainly discuss about uncommon social issues and values that influence his reader for knowing well about phenomenon through his literary works. Indeed, analyzing Galsworthy's literary works will be adorable.

Mr. Gessler as the main character in "Quality" is illustrated as a Germany man that has ambition for gaining his pleasure through create handmade boots for his buyers and his store which has already not worthy to be occupied but he still stand in his situation. It creates unbalance condition from what the researcher seen on him because he does not life properly from his pleasure but he feels happy for it and it about how Gessler face his life when his store is surrounded by luxury stores and the language that he used for communicating with his buyers. Indeed, Gessler is a mysterious man that is why he will be the subject of this research.

Eros and thanatos were being as main theory that will used in this study. It causes in avoiding misunderstanding and unfolding the mindset and knowledge of the readers about life instinct and death instinct that will explain further in this study. Not only about Eros and thanatos but also this study will use the stratification that discuss about language that used by Gessler that has the differences from the narrator. Indeed, these theories will be fabulous for the main character in Galsworthy's Quality. Thus, this paper aimed at analyzing Mr. Gessler's life by using Eros and thanatos which is affected by his stratification.

\section{LITERARY THEORY}

Human being has two basic instincts that will act as their motivator to with Eros as life instinct and thanatos as death instinct (Strachey, 1961, p. 23). "Happiness can be reached by many forms, either good or bad way. This joyful or happy feeling has a strong bound with the energy 
of life, as someone feels happy, he/she can get second energy and get another spirit" (Wilson, 2008, p. 255).

The pleased principle is as same as motivating principle, which is the tendency to avoid pain and to seek pleasure (Chianese, 2007, p. 189) and it also added by Freud in arguing that sensual magnetism indwelling in love is Eros (Freud, 1960). But the contrast is Thanatos: The opposite of Eros - commonly known as the death instinct which goals an aspiration, a drive to be dead and tend to be destructive" (Strachey, 1961, pp. XIV-XV). He added that "Under the circumstances, the term "death instinct" ought to mean an aspiration, a drive to be dead" (Strachey, 1961, pp. XIV-XV).

Furthermore providing the progress of operating stratification attempt regularly and constitutionally rivalry are stratification separation (Giddens \& Held, 1982, p. 4) other theory said that people in upper classes drawn as people who have one or more factories with increasingly replace their machines or properties in order to create quality product (Giddens \& Held, 1982, p. 4) it is as well as between state lower class and upper class are as same as the haves and have nots (1987: 13).

It is as same as the theory that said "classification was taken to mean the 'language conceptual level' i.e. language to categorize objects, people and events in the environment "(Lawton, 1968, p. 36) and also added by Bernstein as quoted in argued that "learning is carried in verbal channels more often in the middle class than in lower class circle "(1994: 370) other theory said that people who is in lower classes or non- standard variation will use their own language (Vandenbussche \& Elspass, 2007, p. 147).

\section{DISCUSSION}

People always follow their good instinct that lead them into their pleasure even if they know what the risks will be happened toward their life but most of people will ignore those risks just for gaining their pleasure. For the example, when students followed competition then they will give full of their efforts include their time for gathering with their family or friends. It is in the interest of being a winner when they are being winner. The efforts that have been taken out by students are called as their risks but being a winner is their good instinct. In psychoanalytic, it argued by Freud that human being has two basic instincts that will act as their motivator to with Eros as life instinct and thanatos as death instinct (Strachey, 1961, p. 23). In Galsworthy's quality, Mr. Gessler who is a boot maker since the narrator was child but he only makes boots when there is a buyer orders for it. Then Galsworthy as the narrator wants to order boot on him but surprisingly Gessler makes his boots without any helper like machine or others. He feels so pleasure when he conduct it by himself that is why most of his customer come from royal family that in loved with his boots because he is comfort and pleased with his handmade boot (Galsworthy, 1912, p. 1). The pleasure that felt by Gessler is kind of his life instinct or Eros because he has already created boot since the narrator was child and there are no significant changes on how he made boots and his store.
This point of view also supported in arguing that "Happiness can be reached by many forms, either good or bad way. This joyful or happy feeling has a strong bound with the energy of life, as someone feels happy, he/she can get second energy and get another spirit" (Wilson, 2008, p. 255). It means that when Gessler wants to achieve his pleased that will lead him a boot which has a good quality for his buyer. So, when Gessler finished his job, he feels like he already fulfils his pleasure and this is called as Gessler's Eros.

Gessler also says a sentence that makes the previous discussion is adequate strong. In Galsworthy's Quality, he said that his boot is not as same as other boots but he thinks his boot is an art. "Id is an Ardt!" (1912: 1) it means that when he is successfully making a great boot for his buyer, he feels like after finished an spectacular art for person who already know or not about the quality of his boot. it is also as well as what philosopher have said that in the pleased principle is as same as motivating principle, which is the tendency to avoid pain and to seek pleasure (Chianese, 2007, p. 189) and it also added by Freud in arguing that sensual magnetism indwelling in love is Eros (Freud, 1960). It means that when Gessler made his boot without any aid and his client feel satisfy with his boot, he finds his pleasure on it and it is belonging to Eros or life instinct.

After he found his pleasure, it gives rise to thanatos will appear in his life because it is impossible if only happy things that happen toward human being's life, meaning that there is a condition that sometimes people do not realize it or even they ignore it. This situation is called as thanatos or death instinct that also happens toward Gessler's life. It is as well as the theory in arguing Thanatos: The opposite of Eros - commonly known as the death instinct which goals an aspiration, a drive to be dead and tend to be destructive" (Strachey, 1961, pp. XIV$\mathrm{XV})$. It means that there is a contrast between Gessler's clients who are rich people and his store. It starts with his boundaries in using machine that is why he never uses any aid even if he is already in modern era like Galsworthy portrays him. And Gessler ignores it just for fulfilling his pleasure and feeling pleased when his buyers satisfied with his boot. His thanatos also happens when his store does not change a lot till he passed away. Even if he feels comfort with his store but the stuff will still in oldfashioned condition or already broke and it will make the owner feels suffer. Gessler also denies about this bad condition in order to gain his pleasure. It is as well as the theory that said "Under the circumstances, the term "death instinct" ought to mean an aspiration, a drive to be dead" (Strachey, 1961, pp. XIV-XV). It also means that death instinct is being one of the reasons why Gessler still stand in his situation but other reason is about the influence of his stratification.

Nowadays, the needs of human are being determinant to classify the strata of individuals because what things or brands are bought by people will be as their label whether they are in upper, middle or lower class in the society. Somehow the common issues toward mindset of some people are when you can buy luxury things mean that you 
are in the upper class but when you cannot buy it, you are labelling in middle or lower class. It is as well as the theory that said furthermore providing the progress of operating stratification attempt regularly and constitutionally rivalry are stratification separation (Giddens \& Held, 1982, p. 4) In Galsworthy's "Quality", it mentions about the characteristic of Mr. Gessler who has boots store but the narrator or writer illustrates it like a store which is small but it is located in famous place in West End. And Galsworthy mentions that the pair of pumps, so inexpressibly slim, the patent leathers with cloth tops, making water come into one's mouth, the tall brown riding boots with marvellous sooty glow, as if, though new, they had been worn a hundred years (Galsworthy, 1912, p. 1). It makes the researcher realize about why Galsworthy drawn Gessler's store like those because of Galsworthy wants to the reader knows about the stratification of Mr. Gessler through the situation of his store. The sentences of "they had been worn a hundred years" determine that Gessler does not change the property in his store even if his store is surrounded by famous store. The illustration of his store portrays his classes that he is in lower classes. It proves in Giddens and Held theory that said people in upper classes drawn as people who have one or more factories with increasingly replace their machines or properties in order to create quality product (1982:4).

Gessler's store is not only describing once but also the narrator describes it twice. The researcher realizes that Galsworthy wants to his reader more concern in the stratification of Gessler that is why he portrays the condition of Gessler's store in many times. Galsworthy also says that One went in, not as into most shops, in the mood of: "Please serve me, and let me go!" but restfully, as one enters a church; and, sitting on the single wooden chair, waited--for there was never anybody there. Soon, over the top edge of that sort of well--rather dark, and smelling soothingly of leather--which formed the shop (Galsworthy, 1912, p. 2) from the words "the single wooden chair", it shows the reader that Gessler's store is small and only two or three persons can enter his store. The small store among big stores on West End and it clearly contextualize that Gessler's stratification is in lower classes. It is in line with the theory that between state lower class and upper class are as same as the haves and have nots (1987: 13). It shows the researcher that Gessler's store is including in have nots or lower class and it also proves that even if his store is hemmed in other luxury stores, Gessler cannot change his stratification and he still can survive on his condition.

The other evidence on Gessler's stratification is talking about his language that he used in his conversation with Galsworthy. The first reason why Gessler has different utterances is about his origin that comes from Germany but the other reason why it is happened, because his stratification is influenced his language. This is happened because of when you are in lower class you cannot accept proper education because your time will concern in looking for your needs and you just receive sober education. The difference utterance of Gessler arises when he talks with the narrator or his buyer like "Id is an Ardt!"(Galsworthy, 1912, p. 1) that sentence should be like it is an art but in his utterance it is so different with common English. It is as same as the theory that said "classification was taken to mean the "language conceptual level' i.e. language to categorize objects, people and events in the environment "(1968: 36) and also added by Bernstein as quoted in argued that "learning is carried in verbal channels more often in the middle class than in lower class circle "(1994:370) it means that how people communicating their language is depended on their education and proper education will only fulfill by upper classes. In this story appears another evidences about the language that has spoken by Mr. Gessler such as "I will ask my brudder," (Galsworthy, 1912, p. 2) the word brudder it supposed to be brother in the right one but the interpretation that Gessler wants to convey the words are same with the true one. It also supported by the theory that said about people who is in lower classes or non- standard variation will use their own language (Vandenbussche \& Elspass, 2007, p. 147). so, Gessler has drawn by the writer as lower class person even if most of his buyers are coming from upper class but he still cannot change his class.

\section{CONCLUSION}

To sum up, people will conduct anything just for gaining their pleased whether it will be good or not for them because mostly the purpose of people give their full efforts is being happy and they comply with what they assume as a good thing. It is inept if people will always life in happy way that is why after people fulfill their Eros then they will ignore or even deny their thanatos just for gaining their pleasure as well as what Gessler has conducted. Gessler does not realize that his thanatos also influenced by his stratification which he cannot change his classes even if his environment or his buyers are coming from royal family or millenials. So, it means when people have already found their pleased in the same times they will find their thanatos and the reasons why they ignore it will appear whether they know it or not.

\section{REFERENCES}

[1] Chianese, D. (2007). Construction and the Analytic Field: History, Scene and Destiny. New York: Routledge.

[2] Freud, S. (1960). The Ego and the Id. W.W. Norton \& Company.

[3] Galsworthy, J. (1912). Quality.

[4] Giddens, A., \& Held, D. (1982). Classess, Power and Conflict. Berkeley/ Los angeles: University of California Press.

[5] Lawton, D. (1968). Social Class, Language and Education. Routledge.

[6] Strachey, J. (1961). Freud, Sigmund.Beyond the Pleasure Principle. (Trans and edited by James Strachey). New York: W.W. Norton \& Company.

[7] Vandenbussche, W., \& Elspass, S. (2007). Introduction: Lower class language use in the 19th century. Multilingua, 26(2-3), 147150.

[8] Wilson, C. (2008). Epicureanism at the Origin of Modernity. (New York: Oxford University Press).

[9] Driver, Edwin D and Driver, Aloo E. 1987. Social Class in Urban India: Essays on Cognitiond and Structures. The Netherlands: E.J. Brill, Leiden. 
[10] Murray, Stephen O. 1994. Theory groups and the study of language in north America a social history. Amsterdam: John Benjamins Publishing Company. 